\title{
Social and Asocial Learning about Climate Change among Institutional Investors: Lessons for Stranded Assets
}

\begin{abstract}
:
Institutional investment portfolios are currently, and will increasingly be, affected by the risks and opportunities resulting from climate change. This paper contributes new empirical data from 58 in-depth interviews and a global investor survey to explore how climate change is being learnt socially and asocially within the institutional investment industry.

This research seeks to identify ways in which the relatively novel concept of 'stranded assets' can be better disseminated to investment professionals. Importantly, both social and asocial learning can affect investment decisions, with some actors usefully providing information via both channels. Better learning, language and leadership within the institutional investment system could facilitate the dissemination of climate and stranded asset discourses among investors, but an imperative to communicate effectively rather than simply communicating more is noted. This paper should interest both investment professionals keen to learn more about the issue and academic researchers seeking to engage investors on these topics.
\end{abstract}

\section{Key Words:}

Climate Change; Communication; Information; Institutional Investment; Learning; Responsible Investment; Stranded Assets 


\section{Introduction}

Institutional investors will be key actors in combating climate change. They are exposed to the risks and opportunities of climate change, and represent a large pool of capital that could help finance the \$53trillion needed to develop a low carbon economy (IEA, 2014). Recognition of these issues within investment institutions appears to be increasing: with membership to groups such as the Principles of Responsible Investment and the Montreal Carbon Pledge growing rapidly (UNEP FI, 2014, IIGCC, 2015). A growing literature highlights how environmental change makes investments across a range of sectors and asset classes at risk from being stranded (Harnett et al. 2014; Caldecott et al. 2013). However, the understanding that environmental factors could strand assets and will have a financial impact on investment portfolios is far from universal (EUROSIF, 2014; Sievänen, 2014).

This paper explores how investors are learning about Responsible Investment (henceforth, RI) topics, seeking to outline which information sources investors use to learn about climate change. It illuminates investors' dependence on both social and asocial learning strategies, and highlights the useful role of some industry actors in providing opportunities for both. This paper uses this exploration of learning to frame recommendations for better communication between academics, researchers and investors on the subject of environmentally-driven stranded assets.

This paper analyzes findings from 58 semi-structured interviews with a range of investment industry professionals to explore the current state of social and asocial learning about climate change and 'stranded assets' within the UK and Australia. These countries were chosen because of the high level of potential stranded asset exposure in their asset markets, and their differing institutional investment structures and climate policies. The Assets Under Management (AUM) of organizations interviewed in Australia equalled A $\$ 778 \mathrm{bn}$, almost $30 \%$ of total A $\$ 2.6 \mathrm{tr}$ AUM (Reserve Bank of Australia, 2015). Interviewed organizations in the UK represented 66.5tr, $24 \%$ of the combined Western Europe and the Middle East ${ }^{1}$ market (BCG, 2015). A global survey of 154 investors provides additional insight.

In defining institutional investors, this study focuses on both asset managers and asset owners, with particular focus on Pension Funds (PF) and Superannuation Funds (SF). Insurance companies are excluded from this study, despite the importance of climate risks to the sector (London Assembly, 2015). Incorporating them would represent an important extension of this research. Throughout this paper the terms 'investor' and 'institutional investor' are used interchangeably.

Sections 2 and 3 explore existing literatures exploring RI and stranded asset debates, and communication and learning theories respectively. Section 4 outlines the methodologies used. Section 5 examines the diversity of information sources used by investors to learn about climate change, before Sections 6, 7 and 8 delve into more detailed analysis of the asocial, social and dual learning strategies of investors respectively. Section 9 explores the need for greater translation of climate science into investable hypotheses. Section 10 offers a discussion and recommendations for the diffusion of stranded asset discourses. Section 11 concludes and highlights useful future research.

${ }^{1}$ Western Europe and Middle East used in calculation due to the geographic scope of interviewed organizations' AUM despite their investment office location in the UK. 


\section{Climate Change, Stranded Assets and Responsible Investment}

Climate change will increasingly impact investment portfolios (OECD, 2012; Wolf, 2014). Institutional investors are likely to be particularly at risk through their role as Universal Owners. Such investors typically have large diversified portfolios, whereby performance is partly reliant on the performance of the economy as a whole and therefore likely to be negatively affected by the range and scale of climate change impacts (Hawley and Williams, 2007). It is predicted that without significant mitigation and adaptation action from governments, businesses, investors and consumers in the coming years, global warming is unlikely to stay below the $2^{\circ} \mathrm{C}$ target of 'acceptable' warming (IPCC, 2014). Beyond this point, feedback loops are likely to accelerate and exacerbate the negative consequences of climate change through a series of 'rolling collapses' within the economy, environment and society (Towers Watson, 2012; World Bank, 2012).

In 2011, the Carbon Tracker Initiative highlighted a potential 'carbon bubble' (Carbon Tracker, 2011), building on Krause et al. (1989) who suggested that fossil fuel companies could be overvalued due to future climate regulation. Research suggests that $60-80 \%$ of publicly listed fossil fuel reserves are 'unburnable' if the world is to avoid disastrous climate changes (Carbon Tracker, 2013; Kepler Cheuvreux, 2014). This would likely be reflected in stranded assets and lower share prices, creating large economic losses among investors, corporations and governments. Stranded assets can occur when 'environmentally unsustainable assets suffer from unanticipated or premature write-offs, downward revaluations or are converted to liabilities' (Caldecott et al. 2013). The impact of asset stranding on investors may be even higher if excess reserves are burnt: subsequent climate changes could irrevocably alter the environment, affecting economic production and investment risk and returns (IPCC, 2014). Asset stranding is already occurring: for example, European gas-fired power stations premature closures cost nearly $€ 6 \mathrm{bn}$ in 2013 (Caldecott and McDaniels, 2014). Carbon Tracker (2016) thus suggests that oil majors could be worth $\$ 100 \mathrm{bn}$ more if they plan for and invest in a $2^{\circ} \mathrm{C}$ world.

Investments which depend on the natural environment, particularly those exposed to the 'stress-nexus' of water-energy-food, are increasingly at risk from such significant premature write-downs as regulation tightens, natural capital is impaired, clean technologies develop and socio-political pressures increase (Harnett et al. 2014). Beneficiaries and NGOs are therefore calling for investors to calculate their exposure to 'stranded assets' risks, catalysing greater corporate engagement and shareholder resolutions against fossil fuel companies (Srinivas, 2015; Dupré et al. 2015). Campaigns for decarbonization and divestment from dirty fossil fuels have also gained momentum (Flood, 2015), with the Divest-Invest movement attracting 500 signatories with $\$ 3.4$ trillion AUM pledging to move capital out of fossil fuels and into environmentally beneficial investments in $2015^{2}$.

RI refers to considering environmental, social and governance (ESG) factors in investment decision-making (EUROSIF, 2012). However, to integrate RI asset owners and asset managers must first learn about their exposure to ESG risks and the

${ }^{2}$ http://divestinvest.org 
investment opportunities available to manage and mitigate these risks. Information asymmetries, a lack of standardized corporate ESG disclosures, and inherent uncertainty and complexity in climate change scenarios all contribute to a lack of information and learning opportunities surrounding RI and hinder its integration into investment decisions (Sievänen, 2014; Eccles and Serafaim, 2013).

This paper compares institutional investor learning about climate change and stranded assets in the UK and Australia. Both investment markets have significant carbon exposure, strong and growing institutional investment systems, and an activism surrounding Responsible Investment (World Bank Database, 2015; EY, 2015). Given the size of institutional investment assets in these two countries, (pension assets are equivalent to the entire annual economic output in both countries [OECD, 2014]), more responsible management of these assets could, potentially, provide significant impetus in shifting capital towards lower carbon economies.

\section{Theories of Learning and Communication}

Learning occurs in both social and asocial environments. Haas and Haas (1995) suggest that capacity to learn is based on the 'willingness to make use of available knowledge' that can be acquired through study, experience, or being taught. Communication, however, is defined in this paper as the imparting or exchanging of information by speaking, writing, or using some other medium. Communication is therefore fundamental to facilitating learning, but is not sufficient: learning depends on the recipient accepting (or rejecting) the information being shared.

\subsection{Asocial Learning}

Asocial learning in this paper will refer to new information that is learned by an individual through the private consumption of information (Pidgeon and Fischhoff, 2011; Rendell et al. 2011). Asocial learning is common in investment decisions, as asset managers often used detailed analysis of raw data on individual companies, sectors and markets (Voss, 2015). The channel of delivery is shown to have a tangible impact on the take-up of information by investors. Easily accessible information within mainstream media has greater stock market impact than the same data released in scientific journals (Huberman and Regev, 2001). Market-wide climate announcements and media coverage are thus more likely to affect investment decisions. A 2012 report found a growing consensus among investors that increased corporate transparency and disclosure could facilitate greater RI, with $80 \%$ saying that ESG data is relevant to investment decision-making (A4S/GRI, 2012). This report also highlighted the diversity of sources used to gather data, with the majority of respondents using multiple channels: direct engagement with companies and formal reporting channels were seen as the most important. This paper expands on and challenges these findings to explore key sources of information and the learning strategies used by investment actors.

\subsection{Social Learning}

Social learning appears to facilitate the rapid dissemination of new ideas, especially when learnt from peers (Hara, 2009) and if practices are expected to have positive 
outcomes (Rotter, 1954). This suggests attention to climate change information is more likely if espoused by investors' co-workers or peers, and also if low-carbon or climate-aware strategies offer good returns (financial and/or reputational). Social learning is perhaps particularly useful for investors who have limited time and attention capacities due to the nature of their jobs (Peng, 2005; Peng and Xiong, 2006).

This section comments on the utility of different social learning theories (summarised in Figure 1) in underpinning the empirics of this paper.

\begin{tabular}{|l|l|l|l|}
\hline Figure 1. Summary of Social Learning Theories (Source: Author) \\
\hline Theory & Key Literature & $\begin{array}{l}\text { Literature Linked To } \\
\text { Climate And/Or } \\
\text { Investment }\end{array}$ & Explanation \\
\hline $\begin{array}{l}\text { Social } \\
\text { Learning }\end{array}$ & $\begin{array}{l}\text { Bandura (1963) } \\
\text { Reed et al. (2010) }\end{array}$ & $\begin{array}{l}\text { Bursztyn et al. (2014) } \\
\text { Nilsson and Swartling } \\
(2009)\end{array}$ & $\begin{array}{l}\text { Learning as a cognitive process that } \\
\text { occurs in social environments rather } \\
\text { than taught environments or through } \\
\text { individual work. }\end{array}$ \\
\hline Peer Learning & $\begin{array}{l}\text { Hara (2009) } \\
\text { Pelling et al. } \\
(2008)\end{array}$ & $\begin{array}{l}\text { Bursztyn et al. (2014) } \\
\text { Cambridge Network } \\
(2015)\end{array}$ & $\begin{array}{l}\text { Collaborative learning amongst peers } \\
\text { is shown to expedite the learning } \\
\text { process. }\end{array}$ \\
\hline Group Norms & $\begin{array}{l}\text { Abrams and Hogg } \\
(1988)\end{array}$ & $\begin{array}{l}\text { Masson and Fritsche } \\
(2014) \\
\text { Whitmarsh et al. (2012) }\end{array}$ & $\begin{array}{l}\text { Social and professional groups } \\
\text { provide guidelines for appropriate } \\
\text { behaviour through the internalization } \\
\text { of accepted behaviours, and the } \\
\text { transfer of accepted knowledges. }\end{array}$ \\
& $\begin{array}{l}\text { Hunlap and McCright } \\
\text { (2008) }\end{array}$ \\
\hline $\begin{array}{l}\text { Fielding et al. (2012) } \\
\text { of Practice }\end{array}$ & $\begin{array}{l}\text { Wenger (2011) } \\
\text { McKeen (2003) }\end{array}$ & $\begin{array}{l}\text { A4S (2015) } \\
\text { Bursztyn et al. (2014) } \\
\text { Guyatt (2007) }\end{array}$ & $\begin{array}{l}\text { Groups of people who share a } \\
\text { concern or a passion for something, } \\
\text { and meet together to discuss and } \\
\text { learn how to improve the situation } \\
\text { through regular cooperation. }\end{array}$ \\
\hline
\end{tabular}

Both formal and informal 'communities of practice' facilitate peer-learning and the dissemination of group norms and practices. Such groups can be formed between colleagues within organizations or external groups promoting cross-collaboration and knowledge-sharing (Smith and Mackie, 2007). In the case of climate change-related investor groups, these communities of practice also promote learning within and between different groups, with some members belonging to multiple groups, so knowledges, identities and norms learned can be transferred between members of different groups (Guyatt, 2007). Social learning can also help to overcome confirmation bias, whereby individuals are prone to selecting information that confirms existing beliefs. This can limit the likelihood of asocial information changing beliefs, compared to exposure to others' opinions and information via social learning (Nickerson, 1998; Jonas et al. 2001).

Rendell et al. (2011) explore the role of peer copying in processing new information. While imitation is an important cognitive process through which we adopt new behaviours, it is also potentially dangerous as the lines of social learning can become entangled in false information. While highly educated investors are perhaps less likely to fall into this trap, 'group-think' and 'herding' are common market traits (Kahneman, 2011). Investors adapt their own decisions based on others' investments due to 'social learning' and 'social utility' (Bursztyn et al. 2014), and this can cause 
herding and market speculation (Devenow and Welch, 1996; Kahneman, 2011). As such, the reasoning and motivations behind any copied behaviour must be considered (Fielding et al. 2014), and asocial learning is required to ensure that up-to-date and accurate information is consumed, particularly when new information is regularly published as is the case in RI and investment markets (Rendell et al. 2011).

\subsection{Communicating Climate Change}

The communication of climate research is important, as the decisions of policymakers, investors and the public will affect future planetary conditions (Painter, 2013). The IPCC has been instrumental in summarizing and publishing the latest climate science (Hulme and Mahony, 2010). However, their ability to communicate these risks effectively remains questionable, with a persistent gap between the climate science, policy action and the public understanding of the risks (Sterman, 2011; Capstick et al. 2014).

A growing literature explores the psychological, social, institutional and political barriers to accepting climate science. To formulate the most effective communication strategy the audience and framing strategies need to be considered (CRED, 2009; Pelling et al. 2008). Moser (2010) suggests that audiences need to 'receive ample, clear, sufficiently strong, and consistent signals that support the necessary changes'. Weigold (2001) and Bostrom et al. (2013) suggest targeting specific audiences; such efforts are beginning to be established in financial communities, with Cambridge University releasing concise, sector-specific, summaries of the IPCC (CISL, 2015). However, significant gaps in disseminating the importance of climate change to investors remains, with Eccles and Serafeim (2013) noting the continued lack of ESG information in quarterly earnings reports which are central to investor's asocial learning. Importantly, simply increasing the amount of information available may not facilitate more efficient learning, and could lead to 'information overload' (Gleick, 2011; Agnew and Szykman, 2010).

This paper thus explores the actors facilitating both social and asocial learning, having identified a significant paucity of academic research exploring different actors' roles in facilitating investor learning on RI topics. This could then usefully inform strategies for academics and industry actors communicating these topics, including stranded assets.

\section{Methodology}

The primary research for this article took place between November 2014 and August 2015. The results are based on a comparative study of 58 in-depth interviews undertaken in the UK and Australia, and a broader global survey of investors.

\subsection{Interviews}

58 interviews were conducted, 29 each in the UK and Australia. Figure 2 provides a tabulated breakdown of the 60 interview participants (one interview in each country was attended by two individuals). As is common in more qualitative business studies, this research utilized convenience sampling instead of more systematic techniques (Eriksson \& Kovalainen 2008). These respondents are thus not presumed to be 
representative of the wider market, but as gaining access to business-people, or 'elites', especially in the financial world, is often particularly difficult (Thomas, 1993; McDowell, 1998; Harvey, 2010), it was decided that the methods and sampling adopted would yield the most interesting and insightful results. Furthermore, snowballing techniques reduced subjectivity, as participants were often willing to suggest additional individuals to interview (Atkinson and Flint, 2001).

\begin{tabular}{|l|c|c|c|c|c|c|c|}
\hline \multicolumn{2}{|l}{ Figure 2. Breakdown of Interview Participants by Role and Organization Type } \\
\hline & $\begin{array}{l}\text { Director } \\
\text { or } \\
\text { Executive }\end{array}$ & $\begin{array}{l}\text { RI } \\
\text { analyst }\end{array}$ & $\begin{array}{l}\text { Investment } \\
\text { manager }\end{array}$ & $\begin{array}{l}\text { Head of } \\
\text { RI }\end{array}$ & Researcher & $\begin{array}{l}\text { Policy } \\
\text { director }\end{array}$ & Total \\
\hline $\begin{array}{l}\text { Asset } \\
\text { Manager }\end{array}$ & 4 & 4 & 7 & 3 & 3 & - & $\mathbf{2 1}$ \\
\hline $\begin{array}{l}\text { Pension } \\
\text { Fund }\end{array}$ & 5 & 8 & 2 & 2 & 1 & - & $\mathbf{1 8}$ \\
\hline $\begin{array}{l}\text { Climate/RI } \\
\text { NGO }\end{array}$ & 5 & 1 & - & - & - & 3 & $\mathbf{9}$ \\
\hline Consultant & 1 & 2 & - & 1 & - & - & $\mathbf{4}$ \\
\hline $\begin{array}{l}\text { Data/ } \\
\text { Research } \\
\text { Provider }\end{array}$ & 2 & - & - & 1 & - & - & $\mathbf{3}$ \\
\hline PF body & 2 & - & - & - & - & 1 & $\mathbf{3}$ \\
\hline Other & 1 & 1 & - & - & - & - & $\mathbf{2}$ \\
\hline Total & $\mathbf{2 0}$ & $\mathbf{1 6}$ & $\mathbf{9}$ & $\mathbf{7}$ & $\mathbf{4}$ & $\mathbf{4}$ & $\mathbf{6 0}$ \\
\hline
\end{tabular}

Existing contacts within the Oxford University Smith School and the economic consultancy Absolute Strategy Research acted as 'gatekeepers' ${ }^{3}$. Emails were sent out to clients of both institutions explaining the research topic and requesting participants; while this provided a range of interviewees, there is some self-selection bias as those most interested in the topic are more likely to respond. Key organizations in RI, including leading NGOs and investment organizations were approached directly following desk-based analysis. These two sampling strategies were used to ensure a diversity of jobs and sectors were represented, and (where possible) the most senior investment or RI individual was targeted. In addition to NGOs, consultants, brokers and data providers, interviewees represented a range of investment sectors, including mainstream asset managers, corporate and public pension funds, ethical funds, infrastructure funds and a sovereign wealth fund.

Interviews were semi-structured, and varied depending on the individuals' profession (mainstream investor, RI professional or intermediary), their interests and experience. Prompt questions were designed in light of existing literature, historical investor surveys and the key research questions. As is often the case in qualitative research, the interview process was an iterative one (Pope et al. 2000): issues raised in early interviews, including an initial pilot interview, provided additional prompts and questions for subsequent interviews (Ziebland and McPherson, 2006). Due to the sensitivity of the information discussed, particularly regarding investment practices, quotations have been anonymised, with references based on their location and the order in which the interviews were conducted (i.e. UK01 and Aus01 for the first interview in each country).

\footnotetext{
${ }_{3}^{3}$ Rice (2010) suggests adopting a business-like or 'inside' approach, using 'gatekeepers' to gain access to initial interviewees.
} 


\subsection{Survey}

A structured, web-based, invitation-only survey was a secondary research method employed to provide broader insights to a consistent set of questions regarding investment learning. A pilot study of 9 individuals, with varying knowledge of climate change and/or investment experience, contributed to the non-linear process of survey creation following the interview process and literature search. The final survey included 29 questions. This survey reduced response bias by randomizing the order in which answer options appeared, and emphasised that results would be shared with participants to increase likelihood of 'true' responses. Both positive and negative phrasing of questions was used and answers were triangulated to ensure that respondents were answering consistently.

The survey was disseminated through the Oxford World Financial Digest (OXWFD), an online news outlet aimed at international investment professionals. This survey accumulated a rich data set of 154 responses: $38.7 \%$ of survey respondents were Executives and a further $27.8 \%$ were Investment Managers. Only 4.7\% were ESG/RI specialists, but $88.3 \%$ of survey respondents said that they were 'somewhat' or 'very' familiar with sustainability investment topics. $40.6 \%$ worked in Asset Management organizations. However, a key limitation of the survey design was that the disclosure of location was not mandated, so almost half of responses are not attributable to a specific country; survey results are thus used to support the interview comparisons of Australia and the UK by providing a broader insight into the global investment market.

\subsection{Data Analysis}

Survey and interview data were analyzed using a number of different techniques, including statistical analysis on quantitative data, and textual analysis on qualitative data. The interview data, where appropriate, has been quantified through tallying responses to structured questions to facilitate comparison to survey data. Coding software 'NVivo' facilitated collective analysis of the data. This software platform helped to organize and analyze data through coding, search, query and visualization tools. Codes were cross-examined and combined to 'understand the patterns, the recurrences' of responses by framing the ways in which data illuminated, questioned and clarified key themes and answered research questions (Miles and Huberman, 1994; Saldana, 2009; Guest, 2012).

The results are specific to the time and place of the research, and my own interpretation and understanding of participants' responses (Schoenberger, 1991). However, every effort has been made to accurately represent the views and data generated, and address biases where possible. The methodologies are clearly outlined, and repeatable in different settings.

\section{Investment Communication Channels}

Only 3 survey respondents (out of 112 responses to this question) and none of the 60 interviewees said that they had 'never' read an article about climate change risks or opportunities. $42 \%$ of survey participants had read an article in the last week. This figure is likely to be higher than normal due to a speech by President Barack Obama announcing America's first national standards to limit carbon dioxide in the week of 
the survey ${ }^{4}$. Regardless of such unintentional event bias, the findings of both methodologies suggest that a market for climate-related information does exist.

We live in the 'Information Age' (Hara, 2009): an era defined by the Internet and online/mobile communication. This has made dissemination of ideas and content much easier, and made data more accessible, with many interviewees using "Internet searching" (Aus07) to source climate information. However, many interviewees noted that "anyone can write anything at any time, its unfiltered, and its not peer reviewed" (Aus11), so additional discernment is often required to determine reliability before the views and ideas can be accepted and learnt from the internet. Investors thus rely on a wide range of sources to triangulate ideas and ensure that they are getting the best information (Voss, 2015).

Figure 3 outlines the range of information sources used by investors to gather and internalise information about climate change, based on interview and survey responses. Information sources that facilitate both social and asocial learning are represented. This demonstrates investors' dependence on both learning types, but also the fact that these strategies are not necessarily mutually exclusive.

\begin{tabular}{|l|l|l|}
\hline Figure 3. List of Information Sources \\
\hline Asocial & Both Asocial and Social & Social \\
\hline Academic publications & Brokers & Experts \\
Company reports & Climate/RI groups & Face to face meetings in work \\
Data providers (ESG) & Consultants & Social discussions outside work \\
Data providers (General) & Internal research & Social media \\
Industry and national bodies & Law firms & \\
Investment journals & NGOs & \\
IPCC reports & Regulators & \\
Lobby group reports & & \\
Mainstream news & & \\
RI news & & \\
\hline
\end{tabular}

Of these sources, interviewees relied on brokers and mainstream data providers most frequently (Figure 4). Both UK and Australia interviewees rely heavily on traditional providers of financial information to source their climate-related information. Further emphasis of the materiality of climate and stranded asset risks within these channels could be key to reaching a broad investment audience. However, more dedicated climate research from climate groups (19 mentions), the IPCC reports and ESG data providers (12 mentions each) are also prominent, particularly in Australia where these sources gained 28 mentions. Australian interviewees typically used a wider range and higher number of information sources.

\footnotetext{
${ }^{4}$ For example, this announcement was widely covered in the Economist, the BBC, the Guardian, CNN, the New York Times and the Wall Street Journal in the week beginning $3{ }^{\text {rd }}$ August 2015. The President said "I am convinced that no challenge poses a greater threat to our future, to future generations, than a changing climate," (The Economist 2015).
} 
Figure 4. Information Sources on Climate Change (Source: Research Interviews)

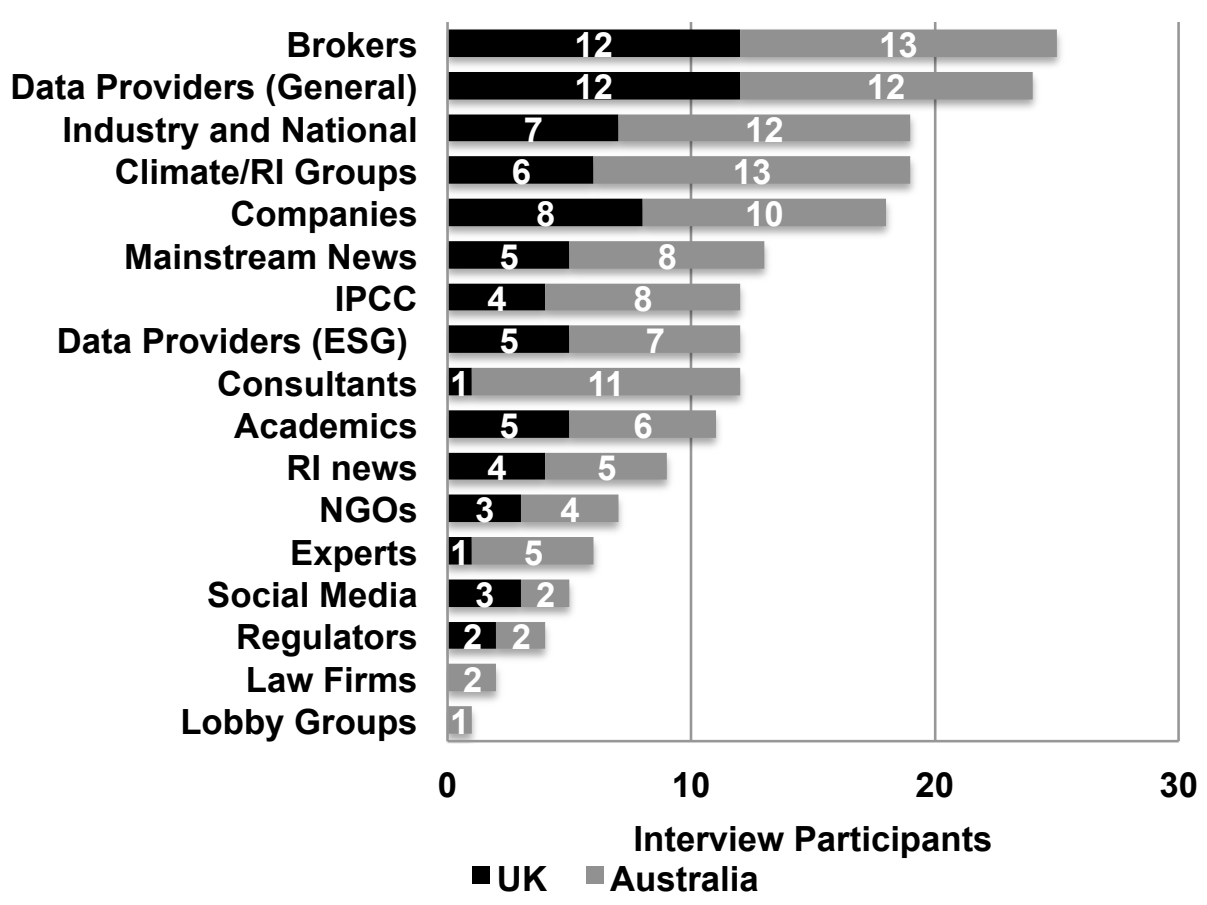

The following sections will outline investors' reliance on social, asocial and dual (social and asocial) learning strategies, analysing the scope and scale of the dissemination of climate information and stranded assets discourses undertaken by different actors.

\section{Asocial Learning Sources}

Asocial learning is seen as key to the diffusion of knowledge about climate change and investment, with access to data, peer-reviewed science and the latest trends in climate and investment all important. The wide range of actors aiding in the asocial dissemination of this information allows investors to access the information they need rather than being at the mercy of their peers' and colleagues' opinions, interests and subjectivities. Appendix 1 and 2 illustrate survey results for information sources used in accessing climate information and sources that inform investment decisions.

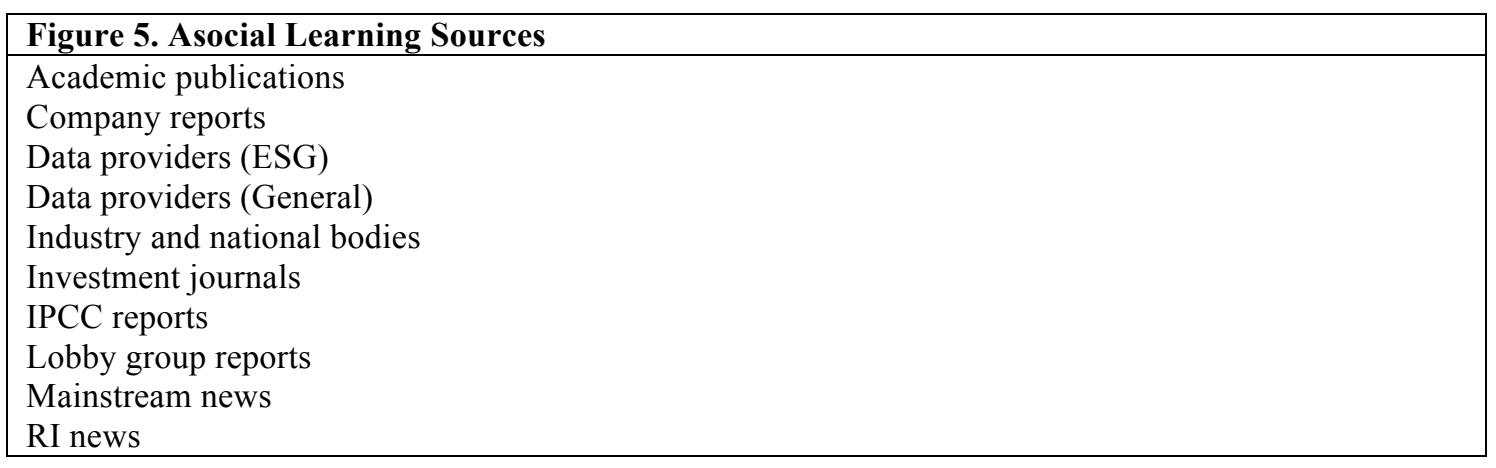


Market data providers are the most relied-upon information by survey participants when making investment decisions (74\% use data regularly or always), but are also key sources of climate information, with 24 interviewees and $54.1 \%$ of global survey participants listing them as an important data source on climate change. This supports the findings of A4S/GRI (2012), which found that formal reporting channels were important sources of ESG information. 16 interviewees mentioned Bloomberg and 12 mentioned the MSCI database as providing good climate and ESG data. Ensuring that climate information is readily available on these platforms is vital to its integration in investment decisions in both the UK and Australia, but awareness of available information varied. There was an expressed frustration that "there is a lot of good research done but it is not taken up" (UK17). Greater discussion within the industry of the data available on these platforms, and efforts to increase the coverage of topics such as stranded assets, could therefore be beneficial.

Corporate reports were also ranked highly in the A4S/GRI (2012) survey findings. However, only 18 interviewees commented on their use (the $5^{\text {th }}$ most common source), and just $27.9 \%$ of survey respondents used corporate reports for climate information, challenging the A4S/GRI finding. $76 \%$ of survey respondents, however, said they use corporate reports to guide their investment decisions; integrating climate information (and its' materiality to financial performance) into annual reports could be key to greater climate awareness within investment decisions.

Mainstream news was the most relied upon information source about climate change among survey participants, with $81.1 \%$ of international survey participants using mainstream news. However, only $13(22 \%)$ interviewees used mainstream news to gather climate information. The wording of the question could have caused this discrepancy: in the survey, 'mainstream media' was referred to as 'newspapers, online content, television etc.', whereas this definition was not clarified in the interviews. Concurrently, the level of climate expertise was greater among interviewees; $50 \%$ of interviewees had a job related to RI compared to only $4.7 \%$ of survey participants. Thus the lower proportion of media usage by interviewees could be due to their greater access to, and confidence in using, specific climate-related data, and greater scepticism around the legitimacy of media reporting: an Asset Management Executive said of climate change "there is a lot talked about it in the media, but a lot of it is fairly alarmist and maybe not very insightful" (Aus14), and another interviewee lamented the "dearth of rigour" in the press (Aus21). However, these results highlight the importance of imbuing mainstream news channels with timely, accurate and relevant climate information for investors, especially as this can help mainstream investors with little alternative information. One interviewee noted that:

"People like Carbon Tracker are trying to make the academic stuff more digestible... It puts it into the more colloquial language and is more impactful... I think using mainstream media and social media is much more effective. I think there is progress being made by the academics and I would support them doing more" (UK25).

Although there has been a proliferation of RI news outlets, websites and blogs, interviewees suggested that these websites have limited outreach to mainstream investors and mostly aid the learning of those already informed and interested in RI issues, with interviewees demanding greater coverage in mainstream channels. 
19 interview participants noted the importance of national, international and industry organization reports in highlighting important climate-related issues, citing the IEA, the OECD and the World Bank as useful sources. These were mentioned more in Australia (12 mentions) than the UK (7 mentions), perhaps due to their focus on broader global and regional scale issues, which were considered more frequently by Australian interviewees. While providing insight into past and future trends, some participants commented that report findings are often difficult to convert into actionable information.

Investment journals were used to gather climate change information by $48.6 \%$ of survey respondents, and in informing investment decisions by $80.7 \%$. Furthermore, 75 survey respondents (69.4\%) used academic reports to help inform their investment decisions at least sometimes, and 12 interviewees discussed the use of the IPCC reports and 11 mentioned using academic articles for learning about climate change. However, many interviewees agreed that academic reports provide general knowledge rather than investment-relevant information: IPCC reports were described as "not necessarily helpful... it provides some evidence but it doesn't necessarily translate that into something that is helpful in terms of making investment decisions" (Aus 17). As such, more work needs to be done in translating the findings of key reports into investment hypotheses, with Section 9 exploring this in more detail. Regardless, it is clear that asocial learning retains an important role in the learning processes of investors, and that those communicating the importance of stranded assets need to ensure that rigorous research is available through a range of asocial channels.

\section{Social Learning Sources}

Social learning opportunities were noted as important in disseminating climate change information through the investment markets, and particularly vital for changing perceptions and beliefs about the materiality of climate change and stranded assets to investment decisions.

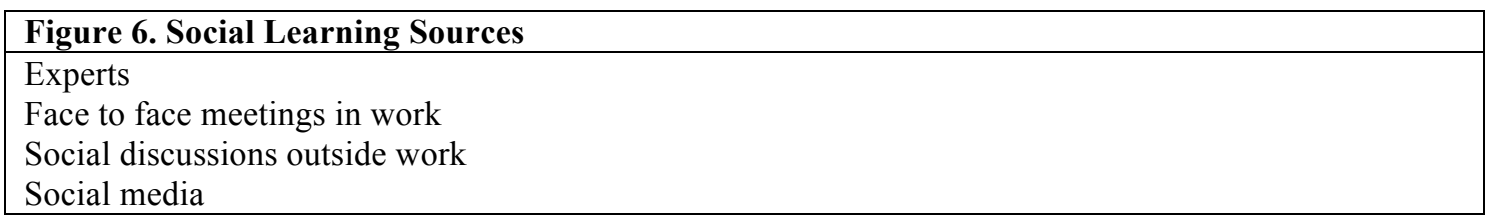

Learning from those of similar experiences, backgrounds and profession is a key knowledge-sharing process (Hara, 2009; Reed et al. 2010), with early-adopters of RI helping to "socialize that message and let it be heard amongst the broader investment and business communities" (Aus16). Groups of peers appear to help normalize discourses and beliefs around the materiality of climate change: "The vast benefit of it is how quickly you can get things done because the existing trust is already there" (Aus28). Although apparent in both the UK and Australia, greater emphasis on informal 'communities of practice' was noted among Australian interviewees, perhaps due to the geographical remoteness, the smaller nature of the industry and the greater reliance on external interaction and cooperation: "Australia is a small place. There are only two cities where anything happens (around RI) and we all know each other" (Aus28). 
Perhaps the most useful social learning technique described by different interviewees was the concept of 'peer-learning':

"I talk to my peers about how they are looking at certain issues; you don't necessarily tell them everything but over time you develop a group that you trust... I think it is hugely important in our field and that information is very useful for us to take internally to use as leverage." (UK24).

Those engaging with such groups saw informal social learning as vital, particularly for RI professionals, with only 9 of the 60 interviewees saying that they favour 'formal' learning over 'informal' learning. Interviewees emphasised the systemic nature of the climate problem, arguing that collaboration was needed to affect the necessary policy and corporate changes: "We felt like we were fighting the same battle so we almost ended up sharing approaches: what worked and what didn't work so that has built a nice platform" (UK17). A novel finding was that social media, including Twitter and LinkedIn, is playing an increasingly important role in disseminating key reports and RI updates, and facilitating peer discussions and the filtering of research.

Top-down leadership is arguably necessary for firm-wide integration of climate considerations (Juravle and Lewis, 2009; Mercer, 2015), and consequently peerlearning among senior managers could stimulate widespread systemic and institutional change. Such networks are perhaps less common due to acute concerns around Chinese Walls, confidentiality and conflicts of interest. However, these groups are beneficial because "everyone struggles to bring case studies to life when it isn't through face-to-face interaction" (UK18). Examples of such high-level 'communities of practice' include the 'Cambridge Leaders Academy CEO Group' 5 and The Prince's Accounting For Sustainability 'CFO Leadership Network'6. The important part of such peer-learning groups is "finding that core group of insiders who can be your advocates. They are respected and seen as credible and are 'one of the club.' Therefore they can say what everyone else may have been saying, but it will be heard" (UK18). Such advocacy among peers from trusted individuals/organizations could be key to overcoming confirmation bias among those sceptical of climate changes' materiality. This suggests that forming smaller groups of Executives supportive of action on climate change and stranded assets could be particularly effective in encouraging RI.

However, the extent of peer-learning internationally was challenged to a certain extent by the survey results: only $26 \%$ used face-to-face meetings to gather information about climate change. This is perhaps suprising given the recent rise of NGO and investor-led groups focusing on this issue, including the Principles of Responsible Investing (PRI), Global Sustainable Investment Alliance and the Global Investor Coalition on Climate Change, which were all noted by interviewees as facilitating useful peer-learning. However, lower participation rates in these groups and the lower proportion of RI specialists meant that survey participants were less likely to undertake specific learning activities on climate change. Furthermore, discussion of climate change was limited within investment institutions surveyed: $83.3 \%$ never have climate change as a standing agenda point in Investment

\footnotetext{
${ }^{5}$ https://www.cambridgenetwork.co.uk/learning/peer-learning/

${ }^{6} \mathrm{http}: / / \mathrm{www}$.accountingforsustainability.org/cfos/network-of-chief-financial-officers
} 
Committee Meetings, and only $12.5 \%$ discussed climate risk 'regularly' or 'always' with clients. While "ad hoc" and "reactionary" discussions about climate change were occurring in investment organizations, evidenced by the $70.5 \%$ of survey participants who discuss it at least sometimes, the lack of formality and frequency identifies the current limit of opportunities for social learning as a barrier to the integration of RI into investment decisions.

Social learning also needs to be moderated by asocial learning to avoid the pitfalls of social 'copying' and 'groupthink' (Rendell et al. 2011) and ensure that participants can stay abreast of scientific and policy developments (Pidgeon and Fischhoff, 2011). One interviewee commented of the informal RI networks "there is insufficient crosspollination of ideas. It's no different to the boys club... It's probably more porous and progressive minded, but you do wonder if there is enough different thinking coming through" (Aus28).

As such, social learning opportunities were acknowledged by interviewees as an especially important learning process around climate change, particularly when encouraged by senior leadership and facilitated by intermediaries and experts. However, it faces challenges from those concerned about competitive advantage, a continued perception that climate change is not material enough to investment decisions, and the relative lack of social learning opportunities for mainstream investors. Greater outreach by RI groups to non-members, and the facilitation of social learning opportunities on stranded assets at mainstream investment events could be key to increasing the dissemination of ideas.

\section{Dual Social and Asocial Learning Sources}

Given the above benefits and limitations to both social and asocial learning, this paper argues that those organizations and communication channels that combine both social and asocial learning opportunities are likely to be most effective.

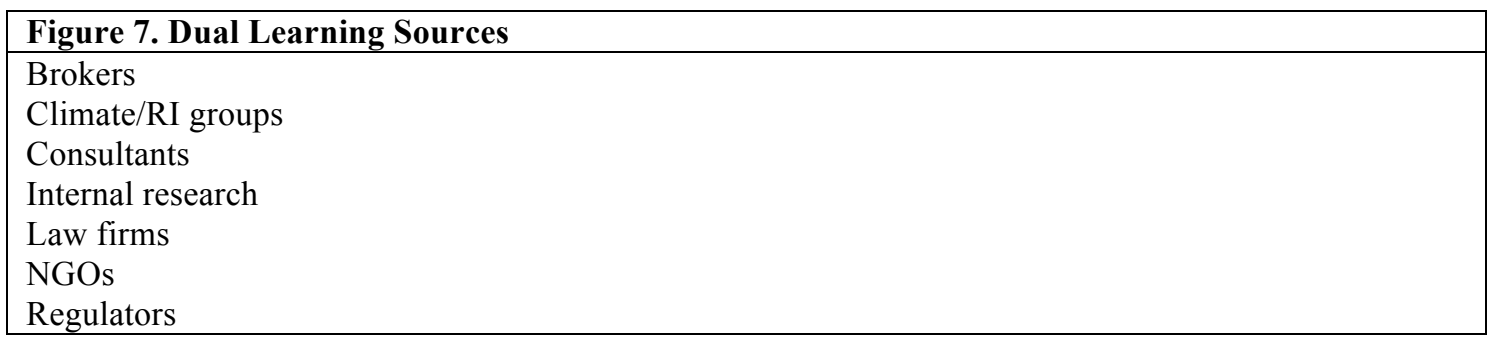

As well as writing their own reports on a range of RI subjects, such actors draw attention to other research reports and facilitate networking and social learning opportunities during client meetings and presentations on key topics, including stranded assets. Several interviewees, particularly in Australia, suggested that such discussions had been key to persuading them that climate change was relevant and could be integrated on a practical level into investment decisions.

External research providers, including brokers and consultants, ranked highly amongst survey and interview participants as key to facilitating learning. More research needs to be done on this topic, as little literature exists on the climate 
research capacity of these groups (c.f. Caldecott and Rook, 2015). 59.5\% of survey participants use external research for climate information, and brokers were the mostdiscussed source of climate information by interviewees in both UK and Australia (25 out of 60 interviewees). One SF RI manager commented "I find that the work done by the brokers is really useful in distilling information into an investment context" (Aus05).

However, not all interviewees were so impressed: an Executive in a sustainabilityfocused AM firm commented, "We have found that traditional 'broking' research is not as long-term oriented or covering these issues as well as we would like" (UK28). Although some brokers are providing useful social and asocial learning on climate issues, coverage varies between brokerage houses and perhaps depends on which stocks and sectors they are broking as to the extent they view climate change and stranded assets as relevant. This supports Dlugolecki and Mansley (2005) who found that brokers tend to be sector-oriented, and focused on emission regulations, with many viewing climate change as too long-term.

Although 12 interview participants mentioned the role of investment consultants in sourcing climate information, 11 of these were Australians, and Mercer was the only investment consultant praised by name for their climate work. The level of coverage of RI issues, and the extent to which climate reports are made public, varies dramatically between organizations, affecting the learning opportunities available to investors. A sustainability NGO director commented: "I have heard of one investment consultant who explicitly didn't cover ESG unless you paid extra for it, even if it was material" (UK05). While almost $50 \%$ of survey participants use consultants in their investment decisions, only 4 'always' use them- the least of any option given. As such, consultants communicating on climate change and stranded assets should perhaps focus on a strategic rather than asset investment level. Interestingly, no participants mentioned management consultants such as McKinsey, who have large environmental research capabilities and products.

NGOs and investor-led groups focusing on climate change provide opportunities for both social and asocial learning. Literature, such as Guyatt (2013), increasingly notes their important role in facilitating RI. 19 interviewees noted their role in primary research, collaborative engagement and networking. 13 of these were Australian interviewees, compared to just 6 in the UK. This difference could perhaps be due to the apparent cohesion within Australia's RI networks centred around the Investor Group on Climate Change (IGCC), which was mentioned as positively impacting the climate policy and investment spheres and facilitating networking. However, whilst climate groups were useful for members, their scope was often seen as simply "preaching to the converted" (UK08). This perhaps reduces their contribution to convincing mainstream investors of the materiality of climate and stranded assets, but once an investor was looking for information these groups were seen as key sources of learning. Interview participants supported greater outreach by these groups.

While most asset management institutions have research teams, there is a growing trend towards establishing in-house RI/ESG research capacity (Bourghelle et al. 2009). 30 of the 58 organizations interviewed had internal climate-related research analysts, but only $24.2 \%$ of survey respondents knew of such capacity. $29.7 \%$ of survey respondents used internal research to learn about climate change and $79 \%$ use 
it in investment decisions, suggesting that there is still a gap between mainstream investment research and climate issues. Although some mainstream researchers cover climate change, an ESG team is perhaps more likely to facilitate social and asocial learning within an organization due to their greater capacity and expertise on these issues. This was clear during the interview process, with ESG researchers more likely than mainstream equivalents to discuss the topic with colleagues and encourage access to reports and data analytics. Such research can play an important teaching role for mainstream investors and can cement decisions about RI at the individual, executive and institutional level.

Bos (2014), however, cautions that 'to accomplish true ESG integration, one should make ESG an integral part of the investment analysis performed by the mainstream analysts'. The success of an ESG team could perhaps be seen in its own demise if it successfully trains mainstream analysts to integrate ESG factors (Arjalies, 2010). However, interviewees argued that "we shouldn't expect our general managers to be experts in everything" (Aus25), and that until ESG integration is further developed, the presence of ESG teams in-house can enable bespoke and practical guidance, in the form of written research, participation in meetings and personal relationships with colleagues which could spark further interest and understanding around climate change and stranded assets exposure.

Regulators and law firms can also provide such social and asocial information, but only a few research participants acknowledged their role explicitly. However, they potentially could play a key role in change industry norms within the investment system towards greater acceptance of $\mathrm{RI}^{7}$.

The dual role of these actors communicating both socially and asocially is implicitly accepted throughout the investment industry, but has gained little attention within the academic literature. Greater explicit attention could facilitate better communication and learning. The organizations explored above could be key to disseminating stranded asset research through their capacity to cater to both social and asocial learning needs of investors, but current focus on climate change by these actors was criticized as concentrated in only a few industry leaders.

\section{Translating the Science}

In addition to understanding the learning mechanisms of investors, and the use of different information sources, it is important to understand what is being communicated, and whether the information is being presented in a relevant manner and language for investors.

"First and foremost, we want to deliver superior performance for our clients. Anything that we have access to that will help us do that, we will look at. The challenge is then to prove that is material. A lot of progress has been done in terms of the ESG quality of the analysis but we still have quite a way to go"(UK24)

\footnotetext{
${ }^{7}$ For example, law firms Minter Ellison and Client Earth are producing novel research and litigation emphasizing investors' institutional and individual liability to climate risks, and the Bank of England has been pioneering in its' capacity as a regulator calling for greater accounting for stranded asset and climate exposure in investment portfolios. Both types of organization provide written research as well as attending client meetings and running workshops.
} 
Survey data found that many financial actors still feel that there is not enough information available, with only $20 \%$ of 110 survey respondents saying that there is adequate information to properly analyze corporate exposure to climate change. In contrast, $70 \%$ of interviewees ( 25 interviewees out of 36 interviewees that commented on this issue) said that there is sufficient information available on climate change: comments included "This is not an information problem" (UK19) and "I don't think getting hold of information is a problem" (UK04). Furthermore, five Australian and six UK participants said that there was "too much information", with seven interviewees mentioning that they suffered from "information overload" (3 in Australia, 4 in the UK). This variation in views between the survey and interview participants was pronounced, and again can be linked to the greater proportion of interviewees having an RI capacity in their job and involvement in RI groups, perhaps leading to confirmation bias whereby those convinced by the climate science seek out more information than those still sceptical of its' relevance to investment decisions. Even though climate-related research and corporate disclosures are being released through a range of platforms, it is not fully integrated into decision-making. This is perhaps where more RI teams, consultants and brokers could become important conduits for research and the education of investors around the availability and use of existing climate information.

Translating academic knowledge into an actionable investment thesis is key to its integration into investment decision-making (UNEP FI, 2009). This translation is currently inadequate: only $30 \%$ of survey participants said that the language used in climate change communications was appropriate for the investment community. Climate communications were seen as "politicized", "full of jargon or difficult to follow" and "alarmist arguments". The lack of funding for climate-related investment research could be one reason for the deficit of investor-appropriate language and research, with only $4.7 \%$ of survey respondents knowing of climate research budgets within their organization. Alongside technical and non-relevant language, interviewees in both countries also commented that most climate reports were too long: "when a big report comes through on climate that is relatively technical that might be 50 or 100 pages, I find it very hard to read" (Aus13). Another said: "Time is a major factor for me and for investment teams. So generally good, concise exec summaries are the things I like to look at" (Aus15). This corroborates Peng (2005), which posits that investors have limited time and attention for learning and processing information. This should act as a warning for those communicating stranded assets to investors: simply providing more information is not sufficient to increase consideration of ESG factors and stranded assets, the information needs to be relevant to investment decisions, and of a suitable language and length.

However, a desire for more and different information does exist. Figure 8 explores the additional information desired by survey respondents, finding that $58.7 \%$ wanted better data on how climate change is affecting portfolio/economy returns, and $46.8 \%$ wanted better company data on exposure to climate change. Such efforts are already underway in academia and industry, such as Caldecott et al. (2016) which explores asset-level exposure to climate change among thermal coal assets, but these are still limited in their scope and impact. 
Figure 8. What addition information would be helpful to better account for climate change in investment decisions? (Source: Research Survey)

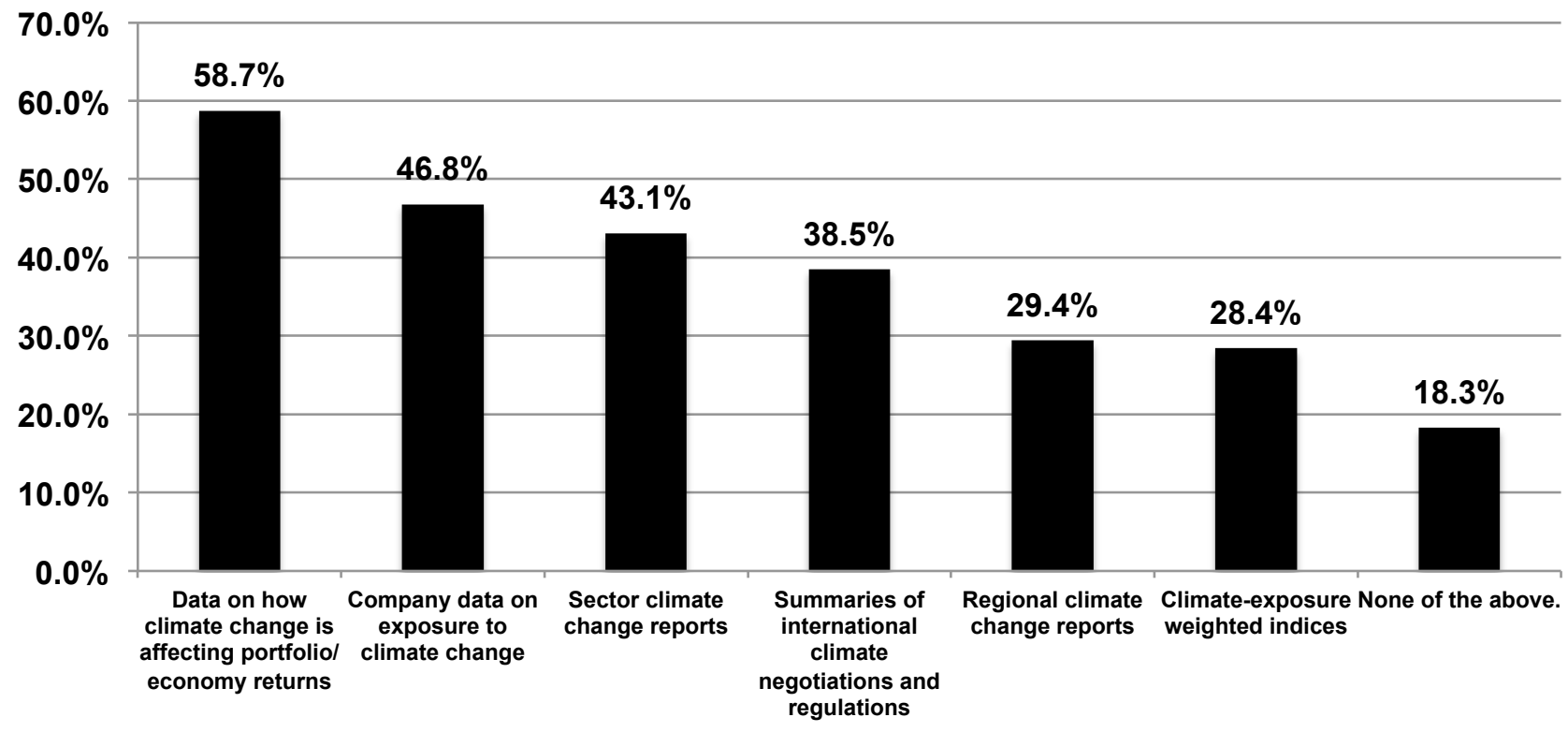

Furthermore, the timelines and immediate relevance of climate risks were also noted as important by interviewees. One interviewee commented that translating the science into investment actions was difficult: "given the nature of climate change it is very difficult to pin down when certain things are going to occur, so that has made it quite challenging" (Aus15). 38.5\% of survey respondents said that summaries of policies and regulation could enhance understanding of likely impacts and the time-frames for investment exposure. Time-frames around stranded assets was highlighted as being potentially useful, with one asset manager saying "if you had some models where you could point to stranding potential then that would be more helpful" (UK09). Another said "unless you can put a value and a timeline on the stranding then it isn't that helpful for investors" (UK10).

Both UK and Australian interviewees suggested the need for more high-profile case studies and mainstream coverage of the materiality of climate, the need for more investment products that offered opportunities to benefit from the low carbon transition, and praised work that shifted discourses from moral campaigns towards material financial risks, such as being done by those interested in stranded assets:

"I think that the recent work ... by groups like Carbon Tracker around stranded assets, backed up by the IPCC findings around the carbon budget, has helped to present to investors a much simpler thesis" (Aus16)

As such, greater focus on examples and timelines of stranded assets could help emphasising the materiality of climate change to current and future investment decisions, but this needs to be communicated clearly through both social and asocial learning opportunities. 


\section{Discussion}

Existing academic literature has given only limited attention to the issue of how mainstream investors are most efficiently and effectively informed about climate change exposure, and how these ideas inform investment decision-making. This analysis should help frame future research and communication aimed at translating climate science and stranded assets risks for the investor audience. Importantly, this paper has identified the on-going demand for this information and the need to communicate through a range of social and asocial learning opportunities. Specifically, better understanding, funding and outreach among those actors offering dual learning methods could be particularly advantageous.

Australian interviewees, who tended to use a wider range of information sources, mentioned information provided by consultants and climate groups more frequently suggesting that there is greater knowledge sharing between firms in Australia. UK interviewees relied more heavily on internal research teams, perhaps due to the greater scale and capacity of these teams due to the differing nature of the investment industry. The failure of investment firms to explicitly budget for purchasing thirdparty climate change related investment research could be limiting the amount of information of a suitable length, language and detail available to help investors integrate climate into everyday decisions. Further emphasis on the materiality of climate change for financial risk and return facilitate greater efforts towards RI, with stranded asset discourses praised as helping in this process. Such information and discourses could lead to greater consideration of these risks at the Investment Committee Meetings and C-suite level, which might increase demand for, and integration of, such information. A novel finding was the increasing role of social media in providing a filter and sharing platform within the RI profession, providing a channel for reaching wider audiences and reducing the risk of information overload.

Investors in both the UK and Australia engage in social and asocial learning about climate change and stranded assets. This research suggests scope for further development of informal 'communities of practice' within the investment system for learning about stranded assets, with such groups facilitating social peer-learning and asocial knowledge development through sharing of climate research. Such networking opportunities could be particularly important among Executives, where the greatest leverage exists for firm- and industry-wide change. Executive networking opportunities already exist to a limited extent in the UK, but could be scaled up in both the UK and Australia in line with existing formal and informal networks of RI professionals. Networks of individuals and the role of social learning appeared stronger in Australian than in the UK, possibly a result of the geographic remoteness and small scale of the investment industry, causing a greater reliance on collaboration and knowledge sharing. However, the multiple climate groups in both countries need to be more aware of reaching out beyond their own networks to ensure that the benefits of peer-learning and research reports extend beyond RI professionals to mainstream investors and that members continue to learn about new discourses such as stranded assets.

As such, this paper recommends that those wishing to disseminate stranded asset discourses use a co-ordinated communication strategy. This should tap into the diversity of information sources and learning strategies used by investors. Simply 
producing more detailed research or organizing conferences about the likelihood and impacts of stranded assets, although needed, will not be sufficient to convince investors of the merits of the concept or facilitate its' integration into investment decisions. Targeting information specifically for investors, and encouraging internal mainstream and RI researchers to write their own research, synthesise key reports and hold regular meetings with peers and colleagues to discuss these topics could aid the translation of academic science of stranded assets and climate change into investment hypotheses. A key recommendation resulting from these findings is the need for researchers' to focus their engagement with organizations that regularly engage investors through both social and asocial learning opportunities, notably climate groups, consultants, internal research teams and brokers. This could be key to catalysing greater learning about stranded assets, building on investors' dual learning and informational needs. However, mainstream media and data platforms remain particularly important for those investors not already aware of climate and stranded asset concepts, so concise, rigorous and easily accessible information on these platforms will also be key to catalysing a shift towards a lower carbon economy and more Responsible Investment.

\section{Conclusions and Future Research}

This paper has explored the learning surrounding climate change and stranded asset risks within institutional investment organizations in the UK and Australia. These countries were chosen because of the high level of climate change exposure in their asset markets, and their differing institutional investment structures. As an extension to this research, American, European and Asian institutional investors could be studied using the same methodologies to expand comparisons and understandings of learning and Responsible Investment within the international institutional investment system. Similarly, a study of how the insurance industry is learning about these longterm climate risks could be interesting future research.

Changing investment behaviour to take greater account of climate-related issues and stranded asset risks is possible, and already occurring, but this research suggests that there remains scope for this to be scaled up and intensified. Increased collaborations, communication and peer-learning are needed, and greater recognition of the benefits of offering both social and asocial learning opportunities could further facilitate the dissemination of the stranded assets concept. Better learning, language and leadership within the institutional investment system could stimulate greater integration of climate change thinking and accounting for stranded asset exposure, but could also, perhaps, help push private capital towards funding the estimated $\$ 53 \mathrm{trn}$ of investment required to deliver a more sustainable, lower carbon global economy. 


\section{Appendix 1. Climate Change Information Sources}

\section{How do you gather information on climate change issues?}

(Source: Research Survey)

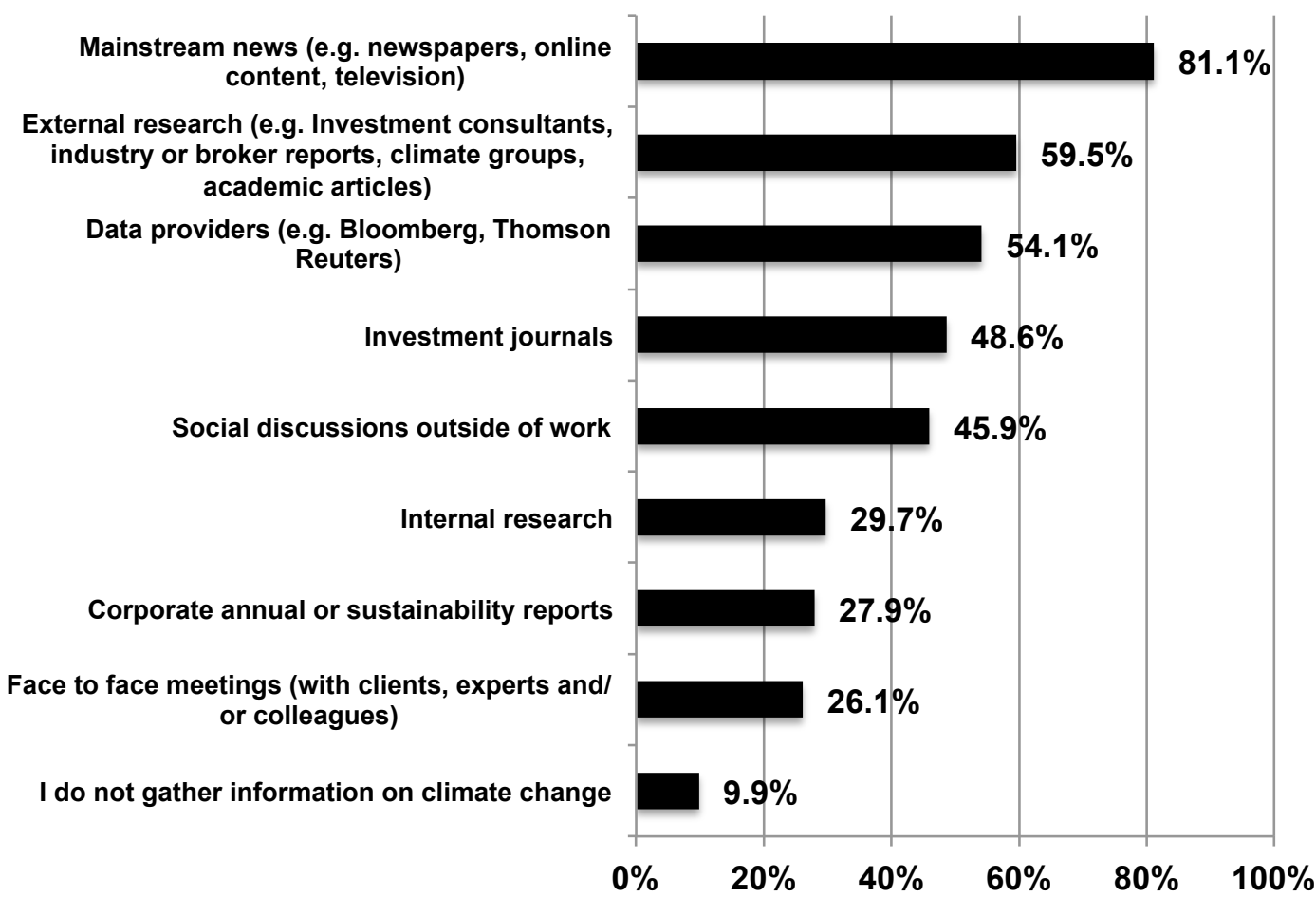




\section{Appendix 2. Investment Decision Information Sources}

When making investment decisions, what forms of communication do you utilise? (Source: Research Survey)

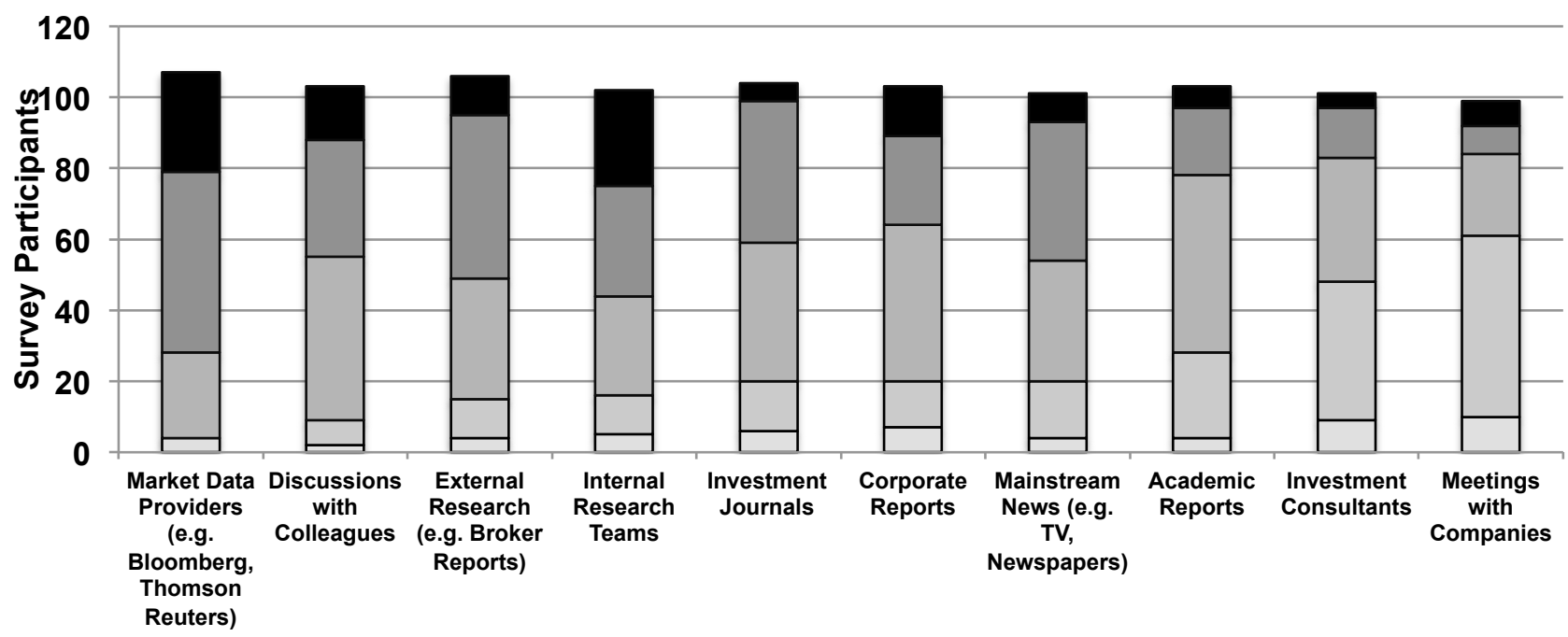

$\square$ Don't Know / Not Applicable $\square$ Never $\square$ Sometimes $\square$ Regularly always 


\section{References}

A4S (2015) The A4S CFO Leadership Network. The Prince's Account for Sustainability. [Online]. Available from:

$<$ http://www.accountingforsustainability.org/cfos/network-of-chief-financialofficers $>$ (Accessed June, 2015).

A4S / GRI (2014) “What Investors And Analysts Said” - The Value Of ExtraFinancial Disclosure. London: The Prince's Accounting for Sustainability Project and the Global Reporting Initiative.

Abrams, D. and Hogg, M.A. (1988) Comments On The Motivational Status Of SelfEsteem In Social Identity And Intergroup Discrimination. European Journal of Social Psychology, 18 (4), pp. 317-334.

Agnew, J.R. and Szykman, L. (2010) Annuities, Financial Literacy And Information Overload. Pension Research Council WP, 33.

Arjalies, D. (2010) A Social Movement Perspective on Finance: How Socially Responsible Investment Mattered. Journal of Business Ethics, 92, pp. 57-78.

Atkinson, R. and Flint, J. (2001) Accessing Hidden And Hard-To-Reach Populations: Snowball Research Strategies. Social research update, 33 (1), pp. 1-4.

Bandura, A. (1963) The Role Of Imitation In Personality Development. Dimensions of Psychology, pp. 16.

BCG (2015) Global Wealth 2015: Winning the Growth Game. Boston Consulting Group.

Bos, J. (2014) Integrating ESG Factors in the Investment Process. CFA Institute Magazine, January 2014.

Bostrom, A., Böhm, G. and O'Connor, R.E. (2013) Targeting And Tailoring Climate Change Communications. Wiley Interdisciplinary Reviews: Climate Change, 4 (5), pp. 447-455.

Bourghelle, D., Jemel, H. and Louche, C. (2009) The Integration Of ESG Information Into Investment Processes: Toward An Emerging Collective Belief? Vlerick Leuven Gent Working Paper Series, 26.

Bursztyn, L., Ederer, F., Ferman, B. and Yuchtman, N. (2014) Understanding Mechanisms Underlying Peer Effects: Evidence From A Field Experiment On Financial Decisions. Econometrica, 82 (4), pp. 1273-1301.

Caldecott, B., Howarth, N. and McSherry, P. (2013) Stranded Assets in Agriculture: Protecting Value from Environment-Related Risks. Oxford: Smith School of Enterprise and the Environment.

Caldecott, B., Kruitwagen, K., Dericks, G., Tulloch, D. J., Kok, I. and Mitchell, J. Stranded Assets and Thermal Coal: An analysis of environment-related risk exposure. Oxford: Smith School of Enterprise and the Environment. 
Caldecott, B. and McDaniels, J. (2014) Stranded Generation Assets: Implications for European Capacity Mechanisms, Energy Markets and Climate Policy.

[Online]. Working Paper, Smith School of Enterprise and the Environment. Available from: http://www.smithschool.ox.ac.uk/researchprogrammes/stranded-assets/Stranded $\% 20$ Generation $\% 20$ Assets $\% 20$ \%20Working\%20Paper\%20-\%20Final\%20Version.pdf. (Accessed August, 2014).

Caldecott, B. and Rook, D. (2015) Summary of Proceedings: Investment Consultants and Green Investment. $3^{\text {rd }}$ Stranded Assets Forum. March 2015. Waddesdon Manor, Oxfordshire.

Cambridge Network (2015) Peer Learning. Cambridge Network. [Online]. Available from: $<$ https://www.cambridgenetwork.co.uk/learning/peer-learning/> (Accessed June, 2015).

Capstick, S., Whitmarsh, L., Poortinga, W., Pidgeon, N. and Upham, P. (2014) International Trends In Public Perceptions Of Climate Change Over The Past Quarter Century. Wiley Interdisciplinary Reviews: Climate Change, 6 (1), pp. $35-61$.

Carbon Tracker (2011) Unburnable Carbon: Are the World's Financial Markets Carrying A Carbon Bubble? London: Carbon Tracker Initiative

Carbon Tracker (2013) Unburnable Carbon 2013: Wasted Capital and Stranded Assets. London: Carbon Tracker Initiative.

Carbon Tracker (2016) Oil Majors Worth More Adopting $2{ }^{\circ} \mathrm{C}$ Pathway, Independent Stress Test Finds. London: Carbon Tracker Initiative.

CISL (2015) IPCC Climate Science Business Briefings. Cambridge Institute for Sustainability Leadership. [Online]. Available from:

$<$ http://www.cisl.cam.ac.uk/business-action/low-carbon-transformation/ipccbriefings $>$ (Accessed June, 2015).

CRED (2009) The Psychology of Climate Change Communication: A Guide for Scientists, Journalists, Educators, Political Aides, and the Interested Public. New York: Center for Research on Environmental Decisions.

Devenow, A. and Welch, I. (1996) Rational Herding In Financial Economics. European Economic Review, 40 (3), pp. 603-615.

Dlugolecki, A. and Mansley, M. (2005) Asset Management and Climate Change. London: Tyndall Centre for Climate Change Research.

Dunlap, R.E. and McCright, A.M. (2008) A Widening Gap: Republican And Democratic Views On Climate Change. Environment: Science and Policy for Sustainable Development, 50 (5), pp. 26-35.

Dupré, S. et al. (2015) Climate Strategies And Metrics: Exploring Options for Institutional Investors. [Online] UNEP FI, 2 Degrees Investing and GHG Protocol. Available from: http://www.unepfi.org/fileadmin/documents/climate strategies metrics.pdf. (Accessed August, 2015).

Eccles, R. and Serafeim, G. (2013) A Tale of Two Stories: Sustainability and the Quarterly Earnings Call. Journal of Applied Corporate Finance, 25 (3). 
Eriksson, P. and Kovalainen, A. (2008) Qualitative Methods in Business Research. Introducing Qualitative Methods series. SAGE Publications.

EUROSIF (2012) SRI Study 2012. EUROSIF.

EUROSIF (2014) SRI Study 2014. EUROSIF.

EY (2015) Tomorrow's Investment Rules 2.0. Ernst \& Young LLP. London

Fielding, K.S., Head, B.W., Laffan, W., Western, M. and Hoegh-Guldberg, O. (2012) Australian Politicians' Beliefs About Climate Change: Political Partisanship And Political Ideology. Environmental Politics, 21 (5), pp. 712-733.

Fielding, K.S., Hornsey, M.J. and Swim, J.K. (2014) Developing A Social Psychology Of Climate Change. European Journal of Social Psychology, 44 (5), pp. 413-420.

Flood, C. (2015) Fossil Fuel Divestment Gathers Momentum. May 3rd ed. London: Financial Times.

Gleick, J. (2011) Information Overload. New Scientist, 210 (2806), pp. 30-31.

Guest, G. (2012) Applied Thematic Analysis. Thousand Oaks, California: Sage.

Guyatt, D.J. (2007) Mobilising Collaborative Opportunities between Pension Funds. Available at SSRN 2033516.

Guyatt, D.J. (2013) Effective Investor Collaboration: Enlarging the Shadow of the Future. Rotman International Journal of Pension Management, 6 (2).

Haas, P.M. and Haas, E.B. (1995) Learning To Learn: Improving International Governance. Global Governance, 1, pp. 255.

Hall, P.A. (1993) Policy Paradigms, Social Learning, And The State: The Case Of Economic Policymaking In Britain. Comparative politics, 25 (3) pp. 275-296.

Hara, N. (2009) Communities of Practice: Fostering Peer-to-Peer Learning and Informal Knowledge Sharing in the Work Place. 1st Ed. ed. Berlin Heidelberg: Springer-Verlag.

Harnett, I., Harnett, E. and Edstrom, E. (2014) Stranded Assets: A New Concept but a Critical Risk. Absolute Thematics Paper. Absolute Strategy Research. London.

Harvey, W.S. (2010) Methodological Approaches For Interviewing Elites. Geography Compass, 4 (3), pp. 193-205.

Hawley, J. and Williams, A. (2007) Universal Owners: Challenges And Opportunities. Corporate Governance: An International Review, 15 (3), pp. 415-420.

Hornsey, M.J. (2008) Social Identity Theory And Self-Categorization Theory: A Historical Review. Social and Personality Psychology Compass, 2 (1), pp. 204-222.

Huberman, G. and Regev, T. (2001) Contagious Speculation and a Cure for Cancer: A Nonevent that Made Stock Prices Soar. The Journal of Finance, 56.

Hulme, M. and Mahony, M. (2010) Climate Change: What Do We Know About The IPCC? Progress in Physical Geography, 34 (5), pp. 705-718. 
IEA (2014) Special Report: World Energy Investment Outlook. France: International Energy Agency / OECD.

IIGCC (2015) Climate Change Investment Solutions: A Guide for Asset Owners. Institutional Investor Group on Climate Change.

IPCC (2014) Summary for Policymakers. In: Climate Change 2014: Impacts, Adaptation, and Vulnerability. Part A: Global and Sectoral Aspects. Contribution of Working Group II to the Fifth Assessment Report of the Intergovernmental Panel on Climate Change. Cambridge, UK: Cambridge University Press.

Jonas, E. et al. (2001) Confirmation bias in sequential information search after preliminary decisions: an expansion of dissonance theoretical research on selective exposure to information. Journal of Personality and Social Psychology 80 (4).

Juravle, C. and Lewis, A. (2009) The Role of Championship in the Mainstreaming of Sustainable Investment (SI): What Can We Learn From SI Pioneers in the United Kingdom? Organization \& Environment, 22 (1), pp. 75-98.

Kahneman, D. (2011) Thinking, Fast and Slow. New York: Farrar, Straus and Giroux.

Kepler Cheuvreux (2014) Stranded Assets, Fossilised Revenues. Energy Transition and Climate Change. ESG Sustainability Research, Kepler Cheuvreux.

Krause, F., Bach, W. and Koomey, J. (1989) Energy Policy in the Greenhouse. London: Earthscan Books.

London Assembly (2015) Weathering the Storm: The Impact of Climate Change on London's Economy. London: London Assembly Economic Committee.

Masson T. and Fritsche I. (2014) Adherence To Climate Change-Related Ingroup Norms: Do Dimensions Of Group Identification Matter? Eur. J. Soc. Psychol., 44, pp. 455-465.

McDowell, L. (1998) Elites in the City of London: Some Methodological Considerations. Environment and Planning A, 30 (12), pp. 2133-2146.

Mercer (2015) Investing in a Time of Climate Change. Mercer.

Miles, M.B. And Huberman, A.M. (1994) Qualitative Data Analysis: An Expanded Sourcebook. Sage.

Moser, S.C. (2010) Communicating Climate Change: History, Challenges, Process And Future Directions. Wiley Interdisciplinary Reviews: Climate Change, 1 (1), pp. 31-53.

Nickerson, R. (1998) Confirmation Bias: A Ubiquitous Phenomenon in Many Guises. Review of General Psychology, 2 (2).

Nilsson, A.E. and Swartling, Å.G. (2009) Social Learning About Climate Adaptation: Global And Local Perspectives. Stockholm Environment Institute, Working Paper.

OECD (2012) The Role of Institutional Investors in Financing Clean Energy. OECD Working Papers on Finance, Insurance and Private Pensions.

OECD (2014) Pension Markets in Focus 2014. OECD. 
Painter, J. (2013) Climate Change in the Media: Reporting Risk and Uncertainty. University of Oxford.

Pelling, M., High, C., Dearing, J. and Smith, D. (2008) Shadow Spaces For Social Learning: A Relational Understanding Of Adaptive Capacity To Climate Change Within Organizations. Environment and Planning A, 40 (4), pp. 867884.

Peng, L. (2005) Learning with Information Capacity Constraints. Journal of Financial and Quantitative Analysis, 40 (2).

Peng, L. and Xiong, W. (2006) Investor Attention, Overconfidence and Category Learning. Journal of Financial Economics, 80 (3), pp. 563-602.

Pidgeon, N. and Fischhoff, B. (2011) The Role Of Social And Decision Sciences In Communicating Uncertain Climate Risks. Nature Climate Change, 1, pp. 3541.

Pope, C., Ziebland, S. and Mays, N. (2000) Qualitative Research In Health Care. Analysing Qualitative Data. BMJ (Clinical research ed.), 320 (7227), pp. 114116.

Reed, M. S. et al. (2010) What is Social Learning? Ecology and Society, 15 (4).

Rendell, L., Fogarty, L., Hoppitt, W.J., Morgan, T.J., Webster, M.M. and Laland, K.N. (2011) Cognitive Culture: Theoretical And Empirical Insights Into Social Learning Strategies. Trends In Cognitive Sciences, 15 (2), pp. 68-76.

Reserve Bank of Australia (2015) Recent Developments in Asset Management. Reserve Bank of Australia, June Quarter Bulletin.

Rice, G. (2010) Reflections On Interviewing Elites. Area, 42 (1), pp. 70-75.

Rotter, J.B. (1954) Social Learning And Clinical Psychology. New Jersey, US: Prentice-Hall.

Saldana, J. (2009) The Coding Manual for Qualitative Researchers. Thousand Oaks, California: Sage Publications.

Schoenberger, E. (1991) The Corporate Interview As A Research Method In Economic Geography. The Professional Geographer, 43 (2), pp. 180-189.

Sievänen, R. (2014) Practicalities Bottleneck To Pension Fund Responsible Investment? Business Ethics: A European Review, 23, pp. 309-326.

Smith, E.R. and Mackie, D.M. (2007) Social Psychology. 3rd ed. Psychology Press.

Smith, H.A. and McKeen, J.D. (2003) Creating And Facilitating Communities Of Practice. In Handbook On Knowledge Management: Knowledge Matters., ed. C.W. Holsapple, 1st ed. Springer, pp. 393-407.

Srinivas, S. (2015) Investors Ask Oil Companies To Disclose Refineries' Risks From Climate Change. February $27 \mathrm{ed}$. The Guardian.

Sterman, J.D. (2011) Communicating Climate Change Risks In A Sceptical World. Climatic Change, 108 (4), pp. 811-826.

The Economist (2015) Hotter than August. The Economist. August $8^{\text {th }}$. Available from: http://www.economist.com/news/united-states/21660548-new-rules- 
curb-emissions-power-plants-are-not-bold-they-seem-hotter. (Accessed March 2016).

Thomas, R.J. (1993) Interviewing Important People In Big Companies. Journal of Contemporary Ethnography, 22 (1), Pp. 80-96.

Towers Watson (2012) We Need A Bigger Boat: Sustainability in Investment. London: Towers Watson.

UNEP FI (2009) The Materiality of Climate Change: How Finance Copes With the Ticking Clock. Switzerland: United Nations Environment Programme Finance Initiative.

UNEP FI (2014) Financial Institutions taking action on Climate Change. UNEP Finance Initiative.

Voss, J. (2015) Where to Find Valuable Investment Information. CFA Institute. Available from: https://blogs.cfainstitute.org/investor/2015/08/20/where-tofind-valuable-investment-information/. (Accessed January 2016).

Weigold, M.F. (2001) Communicating Science: A Review of the Literature. Science Communication, 23 (2), pp. 164-193.

Wenger, E. (2011) Communities of Practice: A Brief introduction.

Whitmarsh, L., Lorenzoni, I. and O'Neill, S. (2012) Engaging the Public with Climate Change: Behaviour Change and Communication. New York: Taylor and Francis; Earthscan.

Wolf, M. (2014) A Climate Fix Would Ruin Investors. The Financial Times, (June 17 th).

World Bank (2012) Turn Down the Heat: Why a $4{ }^{\circ} \mathrm{C}$ Warmer World Must Be Avoided. The World Bank Group.

World Bank Database (2015) Carbon Emissions Per Capita. Online: World Bank.

Ziebland, S. and McPherson, A. (2006) Making Sense Of Qualitative Data Analysis: An Introduction With Illustrations From Dipex (Personal Experiences Of Health And Illness). Medical Education, 40 (5), pp. 405-414. 